\title{
Typing of Candidemia Agents of Candida albicans Isolates by Molecular Methods and Investigation of SAP4 Gene Presence
}

\section{Kandidemi Etkeni Candida albicans Sușlarının Moleküler Yöntemlerle Tiplendirilmesi ve SAP4 Geni Varlıg̃ının Araștırılması}

\section{Kemal BiLGiN'(iD), Asuman BiRINCil(ID), Tuba YILDIRIM²(ID)}

\footnotetext{
${ }^{1}$ Department of Medical Microbiology, Faculty of Medicine, Ondokuz Mayis University, Samsun, Turkey

${ }^{2}$ Department of Biology, Faculty of Arts and Sciences, Amasya University, Amasya, Turkey
}

* This study was presented as a poster presentation at $36^{\text {th }}$ Turkish Microbiology Congress.

Cite this article as: Bilgin K, Birinci A, Y.ldirrm T. Typing of candidemia agents of Candida albicans isolates by molecular methods and investigation of sap4 gene presence. FLORA 2020;25(3):316-24.

\begin{abstract}
Introduction: In recent years, increasing infections due to fungi have drawn attention. Especially, Candida albicans is the most frequent infectious agent with its virulence factors. Furthermore, because C. albicans is a nosocomial infection agent, it can lead an increase in mortality and morbidity. In this study, it was aimed to genotype C. albicans strains that caused candidemia by molecular methods and to investigate one of the most important virulence factors, Secreted Aspartyl Proteinase 4 (SAP4).

Materials and Methods: Our study included 50 C. albicans strains isolated from blood cultures. The isolates were identified both phenotypically and genotypically. Arbitrarily-Primed Polymerase Chain Reaction (AP-PCR) and Pulsed Field Gel ElectrophoresisElectrophoretic Karyotype Analysis (PFGE-EK) methods were used for molecular genotyping of the strains. Furthermore, the presence of SAP4 a virulence factor for $C$. albicans was investigated by polymerase chain reaction (PCR).

Results: The 50 C. albicans isolates included in our study were separated to 26 genotypes by AP-PCR, 41 genotypes by PFGE-EK, and SAP4 was detected in 49 of the 50 isolates.

Conclusion: In conclusion, dominant genotypes among the C. albicans isolates were not detected. Results of both molecular typing methods revealed that C. albicans isolates were generally endogenous. Furthermore, SAP4 gene was detected in $98 \%$ of the isolates. A considerable presence of this gene in blood sample isolates suggests that it contributes to systemic infections. More elaborative studies on the function of SAP4 gene in endogenous infections of C. albicans may contribute to the prevention of these infections in the future. Key Words: Candida albicans; Pulsed field gel electrophoresis; Virulence factor
\end{abstract}




\title{
Öz
}

\section{Kandidemi Etkeni Candida albicans Sușlarının Moleküler Yöntemlerle Tiplendirilmesi ve SAP4 Geni Varlıg̃ının Araștırılması}

\author{
Kemal BiLGiN'1', Asuman BiRINCi', Tuba YILDIRIM² \\ ${ }^{1}$ Ondokuz Mayıs Üniversitesi Tıp Fakültesi, Tıbbi Mikrobiyoloji Anabilim Dalı, Samsun, Türkiye \\ ${ }^{2}$ Amasya Üniversitesi Fen-Edebiyat Fakültesi, Biyoloji Bölümü, Amasya, Türkiye
}

Giriş: Son yıllarda mantarlara bağı infeksiyonlarda ciddi artış dikkati çekmektedir. Özellikle Candida albicans sahip olduğu virülans faktörleri sayesinde en sık karşılaştığımı infeksiyon etkenlerindendir. Ayrıca, C. albicans önemli bir hastane infeksiyonu etkeni olarak, morbidite ve mortalite artışına neden olabilmektedir. Bu çalışmada; kandidemi etkeni C. albicans suşlarının moleküler yöntemler kullanılarak tiplendirilmesi ve bu mikroorganizmaların virülansında önemli bir rolü olan Salgısal Aspartil Proteinaz 4 (SAP4) gen bölgesi varlığının araştırılması amaçlanmıştır.

Materyal ve Metod: Çalışmaya kan kültürlerinden izole edilen 50 C. albicans suşu dahil edildi. İolatlar fenotipik ve genotipik olarak tanımlandı. Suşların moleküler tiplendirilebilmesi için "Arbitrarily Primed" Polimeraz Zincir Reaksiyonu (AP-PCR) ve "Pulsed Field Gel" Elektroforezi-Elektroforetik Karyotip Analizi (PFGE-EK) yöntemleri kullanıldı. Ayrıca C. albicans için bir virülans faktörü olan SAP4 gen varlığı polimeraz zincir reaksiyonu $(P C R)$ yöntemi ile araştırıldı.

Bulgular: Çalışmaya alınan 50 C. albicans izolatı, AP-PCR yöntemi ile 26, PFGE-EK yöntemi ile 41 genotipe ayrılmıştır ve 50 izolatın 49'unda SAP4 geni varlığı tespit edilmiştir.

Sonuç: Sonuç olarak, çalısılan C. albicans izolatlarında baskın bir genotip saptanmamışır. Her iki moleküler tiplendirme yöntemi sonucunda, C. albicans izolatlarının genellikle endojen kaynaklı olduğu düşünülmektedir. Ayrıca izolatların \%98'inde SAP4 geni tespit edilmiştir. Kan örneği izolatlarında önemli oranda bulunması sistemik infeksiyonlarda bu genin katkısı olduğunu düşündürmektedir. C. albicans'ın endojen infeksiyonlarındaki SAP4 geninin işlevi üzerine daha ayrıntılı çalışmalar gelecekte bu infeksiyonların önlenmesine katkı sağlayabilecektir.

Anahtar Kelimeler: Candida albicans; Pulsed field jel elektroforezi; Virülans faktör

\section{INTRODUCTION}

Candida spp. are frequent causes of invasive fungal infections in immunocompromised hosts and are commonly present as normal flora of the mucosa, skin, vagina, and digestive tract ${ }^{[1,2]}$.

Most of the human infections are caused by Candida albicans ${ }^{[1,3,4]}$. Patients, who have human immunodeficiency virus (HIV) infection, neutropenia, prolonged antimicrobial therapy or therapy with other chemotherapeutic agents, possess a risk for developing disseminated Candida infections ${ }^{[1,2]}$.

In addition, Candida spp. can cause hospital infections. Molecular epidemiology is important for tracking and controlling the infection ${ }^{[5]}$.

C. albicans is an opportunist pathogen which causes various diseases associated with several organs. Not only disruption of the host immune reaction, but also virulence factors have an im- pact on pathogenicity. It is required to analyze the role of each virulence factor at each stage in order to improve the treatment of candidia-

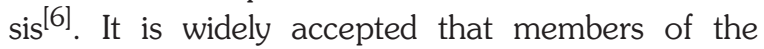
Secreted aspartyl proteinases (SAP) gene family show different expressions at different phases and infection areas ${ }^{[7]}$. In addition, it is declared that C. albicans isolated from the patients with clinical findings has a higher proteolytic activity compared to those obtained from healthy individuals ${ }^{[6]}$.

$\mathrm{SAP}$, one of the most important virulence factors of $C$. albicans, are encoded by 10 SAP genes. Hydrolytic enzymes produced by SAP4, one of the secreted aspartyl proteinases, are effective in systemic infections ${ }^{[8-10]}$.

The aim of this study was to type $C$. albicans strains using molecular methods and to investigate the SAP4 gene, which has an important role in the virulence of these microorganisms. 


\section{MATERIALS and METHODS}

\section{Isolates}

The study included $50 \mathrm{C}$. albicans strains isolated in routine microbiology laboratory from the blood samples of patients hospitalized at various departments. C. albicans strains grown in blood cultures after 48 hours of hospitalization or 10 days after discharge of the patient were included into the study. The isolates were collected by re-sampling, and information on service and date of isolation were recorded.

Isolates from pure cultures were transferred into Eppendorf tubes containing sterile physiological saline solution and stored at room temperature. Before testing, strains in storage were sub-cultured onto Sabouraud dextrose agar (SDA) (Acumedia, Michigan) twice to ensure purity, then included into the study.

\section{Phenotypic identification of isolates}

The phenotypic identification of the isolates was performed using the germ tube test, Rice Extract-Tween 80 Agar and MAST ID-CHROM agar Candida (Mast Group).

\section{Genotypic identification of the isolates}

The strains identified as $C$. albicans by phenotypic methods were included in the study after being confirmed by species specific Polymerase Chain Reaction (PCR). Using the primers described by Miyakawa et al. for this purpose, the species-specific EO3 gene (125bp) isolated from C. albicans was detected (Table 1$)^{[11]}$. The PCR mixture used for the determination of the EO3 gene and the amplification program were carried out in accordance with the protocols described by Otlu ${ }^{[12]}$.
Typing of $C$. albicans by Arbitrarily Primed-PCR (AP-PCR) method

For molecular typing of $C$. albicans strains by AP-PCR, the DNA extraction method described by Otlu was used for DNA isolations ${ }^{[12]}$.

The reaction mixture used to perform typing by AP-PCR was prepared in accordance with the protocol defined by Durmaz et al. with modifications in the amplification program ${ }^{[13]}$. The primer sequence of M13 used in AP-PCR is given in Table $1^{[14]}$.

The amplification products were subjected to gel electrophoresis process by applying $100 \mathrm{~V}$ electric current for 1 hour followed by $50 \mathrm{~V}$ for 8 hours in $2 \%$ gel (Biomax) in 1xTBE buffer, then stained with distilled water containing $0.5 \mu \mathrm{g} / \mathrm{mL}$ of ethidium bromide for 20 minutes, afterwards the band profile was examined in an imaging device (Biorad, Italy).

The band profile analysis of AP-PCR was performed using the BioNumerics software system. The dendrograms were drawn using UPGMA method (Unweighted pair group method with mathematical averaging) and analyzed by Dice similarity coefficient. For the determination of genotypes, isolates with a similarity coefficient of 96-100\% were defined as same genotype, isolates with a similarity coefficient of $90-95 \%$ were defined as similar strain (subtype), and isolates with a similarity coefficient of $<90 \%$ were defined as different genotype ${ }^{[15]}$.

Typing of $C$. albicans by Pulsed Field Gel Electrophoresis-Electrophoretic Karyotype Analysis (PFGE-EK) method

The karyotyping of $C$. albicans by PFGE was studied by modifying the protocol described by

Table 1. Sequences of primers used in EO3 PCR, AP-PCR and SAP4 PCR

\begin{tabular}{ll} 
Primer & Sequence \\
\hline EO3 Primer1 & 5'--CAC CAA CTC GAC CAG TAG GC--3' \\
EO3 Primer2 & 5'--CGG GTG GTC TAT ATT GAG AT--3' \\
Primer M13 & 5'--GAG GGT GGC GGT TCT --3' \\
SAP4 Primer1 & 5'--CATTCATTCCTTTAATACCGACTATC--3' \\
SAP4 Primer2 & 5'--GGTAACAAACCCTGTAGATCTTTTAA--3
\end{tabular}


Ben Abdeljelil et al ${ }^{[16]}$. The yeasts prepared were stored in $0.5 \mathrm{M}$ EDTA ( $\mathrm{pH}$ 9.0) at $+4^{\circ} \mathrm{C}$ until electrophoresis.

An agarose gel (1\%) (Biorad) was prepared in $100 \mathrm{~mL}$ 0.5xTBE (44.5 mM Trisma base, 44.5 $\mathrm{mM}$ Boric acid, $1 \mathrm{mM}$ EDTA) buffer for electrophoresis. The stored yeasts were cut at a ratio of $1 / 2$ and placed in agarose gel. The electrophoresis was performed under following conditions: $14^{\circ} \mathrm{C}$ temperature, $4 \mathrm{~V} / \mathrm{cm}$ voltage, $120^{\circ}$ angle, initial pulse time of 90 seconds, final pulse time of 325 seconds, total run time of 48 hours.

After electrophoresis was completed, the gel was stained with distilled water containing 0.5 $\mu \mathrm{g} / \mathrm{mL}$ of ethidium bromide for 20 minutes, and the band profile was examined in an imaging device (Biorad, Italy).

The band profile analysis of PFGE-EK was performed using the BioNumerics software system. The isolates with one or more band differences were evaluated as different karyotypes ${ }^{[12,16,17]}$.

\section{Detection of SAP4 gene by PCR}

The reaction mixture for SAP4 PCR was prepared by modifying the protocol of Costa et al. using $0.5 \mathrm{U}$ of Taq DNA polymerase (Fermentas), $200 \mu \mathrm{mol} / \mathrm{L}$ of dNTP, $10 \mathrm{pmol}$ (from each primer), $2.5 \mathrm{mmol} / \mathrm{L}$ of $\mathrm{MgCl}_{2}, 2.5 \mu \mathrm{l}$ of 10xPCR buffer and $2.5 \mu \mathrm{l}$ of $\mathrm{DNA}^{[\mathrm{i} 0]}$.

Primer sequences that amplify the $156 \mathrm{bp}$ region were used ${ }^{[9,10]}$. The primer sequences were given in Table 1.

The amplification program for the SAP4 gene region was carried out by modifying the protocol of Costa et al.: initial denaturation at $94^{\circ} \mathrm{C}$ for 3 minutes, 1 cycle; denaturation at $94^{\circ} \mathrm{C}$ for 30 seconds, annealing at $62^{\circ} \mathrm{C}$ for 50 seconds, extension at $72^{\circ} \mathrm{C}$ for 1 minute, 30 cycles; final extension at $72^{\circ} \mathrm{C}$ for 5 minutes, 1 cycle $e^{[10]}$.

The amplification products were subjected to gel electrophoresis process by applying $100 \mathrm{~V}$ electric current for 1 hour followed by $50 \mathrm{~V}$ for 8 hours in 2\% gel (Biomax) and 1xTBE buffer, then stained with distilled water containing 0.5 $\mu \mathrm{g} / \mathrm{mL}$ of ethidium bromide for 20 minutes, afterwards the band profile was examined in an imaging device (Biorad, Italy).

\section{RESULTS}

The isolates were collected within a period of 18 months. The distribution of the services to which the isolates included in the study were sent is shown in Table 2 .

All isolates included into the study were identified as $C$. albicans by phenotypic methods and the identification was confirmed by EO3 PCR.

\section{AP-PCR Results}

The isolates were divided into 26 different genotypes by the AP-PCR method. The strains with the same genotype (a similarity coefficient of 96-100\%) were as follows: genotype R8A (isolates 18 and 20), genotype R6A (isolates 39 and 8), genotype R10C (isolates 16 and 34), genotype R20A (isolates 35 and 45), genotype R16A (isolates 40 and 41), genotype R1A (isolates 1 and 3), genotype R12A (isolates 21 and 49), genotype R25A (isolates 46 and 47), genotype R5A (isolates 10, 6 and 7). The strains with the same genotype (a similarity coefficient of 90-95\%) were as follows: genotype $\mathrm{R} 8$ (isolates 18, 20, 19 and 12), genotype R6 (isolates 39, 8 and 31), genotype R10 (isolates 42, 44, 16 and 34), genotype R16 (isolates 40, 41, 29 and 28), genotype R2 (isolates 15 and 2), genotype R7 (isolates 14 and 9), genotype R4 (isolates 27 and

\section{Table 2. Service distribution of isolates}

\begin{tabular}{lc} 
Service & Number (\%) \\
\hline Chest diseases & $8(16 \%)$ \\
General pediatrics & $6(12 \%)$ \\
Internal diseases & $6(12 \%)$ \\
Neurosurgery & $5(10 \%)$ \\
Newborn & $5(10 \%)$ \\
Cardiology & $3(6 \%)$ \\
Pediatric infection & $3(6 \%)$ \\
General surgery & $3(6 \%)$ \\
Emergency & $2(4 \%)$ \\
Pediatric intensive care & $2(4 \%)$ \\
Otorhinolaryngology & $2(4 \%)$ \\
Infant & $2(4 \%)$ \\
Gynecology and obstetrics & $1(2 \%)$ \\
Neurology & $1(2 \%)$ \\
Infectious diseases & $1(2 \%)$
\end{tabular}


5), genotype R12 (isolates 21, 49, 22 and 23), genotype R26 (isolates 48 and 50), genotype R5 (isolates 10, 6, 7 and 11).

The strains found to be genotypically identical by the AP-PCR method are shown in Table 3 collectively.

\section{PFGE-EK Results}

The isolates included into the study were divided into 41 different genotypes by the PFGE-EK method. The strains with the same genotype were as follows: genotype P5 (isolates 6 and 7), genotype P33 (isolates 39 and 40), genotype P26 (isolates 32 and 42), genotype P10 (isolates 12 and 21), genotype P19 (isolates 24 and 28), genotype P1 (isolates 1, 17, 18 and 3), genotype P14 (isolates 16 and 44).

The strains which were genotypically identical by PFGE-EK method are shown in Table 4 .

\section{Table 3. The strains found to be genotypically identical by AP-PCR method}

\begin{tabular}{|c|c|c|c|c|}
\hline Genotype & Isolate No & Service & $96-100 \%$ Similarity & 90-95\% Similarity \\
\hline $\mathrm{R} 1 \mathrm{Aa}$ & 1 & Chest diseases & + & \\
\hline $\mathrm{R} 1 \mathrm{Ab}$ & 3 & Neurosurgery & + & \\
\hline R2A & 15 & General pediatrics & & + \\
\hline R2B & 2 & General pediatrics & & + \\
\hline R4A & 27 & Chest diseases & & + \\
\hline R4B & 5 & Pediatric infection & & + \\
\hline R5Aa & 10 & Pediatric infection & + & \\
\hline R5Ab & 6 & Internal diseases & + & \\
\hline R5Ac & 7 & Internal diseases & + & \\
\hline R5B & 11 & Newborn & & + \\
\hline R6Aa & 39 & Newborn & + & \\
\hline $\mathrm{R} 6 \mathrm{Ab}$ & 8 & Gynecology and obstetrics & + & \\
\hline R6B & 31 & Cardiology & & + \\
\hline R7A & 14 & Pediatric intensive care & & + \\
\hline R7B & 9 & Neurosurgery & & + \\
\hline R8Aa & 18 & Newborn & + & \\
\hline $\mathrm{R} 8 \mathrm{Ab}$ & 20 & Otorhinolaryngology & + & \\
\hline $\mathrm{R} 8 \mathrm{~B}$ & 19 & Chest diseases & & + \\
\hline $\mathrm{R} 8 \mathrm{C}$ & 12 & Neurosurgery & & + \\
\hline R10A & 42 & Infant & & + \\
\hline R10B & 44 & Newborn & & + \\
\hline $\mathrm{R} 10 \mathrm{Ca}$ & 16 & Cardiology & + & \\
\hline $\mathrm{R} 10 \mathrm{Cb}$ & 34 & Newborn & + & \\
\hline R12Aa & 21 & General surgery & + & \\
\hline $\mathrm{R} 12 \mathrm{Ab}$ & 49 & Internal diseases & + & \\
\hline R12B & 22 & General pediatrics & & + \\
\hline $\mathrm{R} 12 \mathrm{C}$ & 23 & Internal diseases & & + \\
\hline R16Aa & 40 & Infant & + & \\
\hline R16Ab & 41 & Cardiology & + & \\
\hline R16B & 29 & Infectious diseases & & + \\
\hline R16C & 28 & Pediatric intensive care & & + \\
\hline R20Aa & 35 & Internal diseases & + & \\
\hline R20Ab & 45 & Chest diseases & + & \\
\hline R25Aa & 46 & Pediatric infection & + & \\
\hline R25Ab & 47 & Neurosurgery & + & \\
\hline R26A & 48 & General pediatrics & & + \\
\hline $\mathrm{R} 26 \mathrm{~B}$ & 50 & Neurology & & + \\
\hline
\end{tabular}




\begin{tabular}{lcc}
\multicolumn{3}{l}{$\begin{array}{l}\text { Table 4. The strains found to be genotypically } \\
\text { identical by PFGE-EK method }\end{array}$} \\
\begin{tabular}{lcc} 
Genotype & Isolate No & Service \\
\hline P1 & 1 & Chest diseases \\
& 3 & Neurosurgery \\
& 17 & General pediatrics \\
& 18 & Newborn \\
P5 & 6 & Internal diseases \\
& 7 & Internal diseases \\
P10 & 12 & Neurosurgery \\
& 21 & General surgery \\
P14 & 16 & Cardiology \\
& 44 & Newborn \\
P19 & 24 & General surgery \\
& 28 & Pediatric intensive \\
& & care \\
P26 & 32 & Chest diseases \\
& 42 & Infant \\
P33 & 39 & Newborn \\
& 40 & Infant
\end{tabular}
\end{tabular}

\section{SAP4 PCR Results}

SAP4 gene was detected in 49 of the 50 tested isolates by PCR.

\section{DISCUSSION}

Although $C$. albicans, the most common causative agent of Candida related bloodstream infections, is generally considered to be an endogenous pathogen, it has also been reported that it may be exogenous ${ }^{[5]}$.

Kuzucu et al. have investigated the distribution, antifungal susceptibility and clonal relationship of Candida species isolated from neonatal and pediatric intensive care units of a medical center. At the end of the one-year follow-up, they obtained 28 Candida isolates (15 C. albicans) and used electrophoretic karyotyping and AP-PCR to determine the clonal relationship of these isolates. The M13 primer used in AP-PCR, enabled to obtain a sufficient number of bands $(\geq 10)$ for typing each isolate. They identified 11 genotypes from 15 C. albicans isolates ${ }^{[15]}$.

In our study, M13 primer used in many studies was preferred ${ }^{[12,15,18]}$. In AP-PCR performed using M13, the isolates formed 8-14 band profiles and this is considered to be sufficient for genotyping.
Fifty C. albicans isolates were divided into 26 genotypes by the AP-PCR method. The largest group among these genotypes includes R8, R10, $\mathrm{R} 16, \mathrm{R} 12$, R5 with four microorganisms. It is remarkable that genotype $\mathrm{R} 8$ (isolates 18, 20, 19 and 12) was isolated from different departments but partially isolated on close dates. Three of the four isolates that formed genotype R10 (isolates $42,44,16$ and 34) were isolated from the infancy and neonatal departments where there are pediatric patients, and one from the cardiology department, which has nothing in common with these. Two of the isolates with genotype R16 (isolates 40, 41, 29 and 28) were isolated from the pediatric patients at the intensive care units, while the other two were isolated from the patients hospitalized at infectious diseases and cardiology departments. Two of the genotype R12 (isolates 21, 49, 22 and 23) isolates were isolated from the patients hospitalized in the internal medicine department. The four isolates that formed genotype R5 (isolates 10, 6, 7 and 11) were isolated on close dates; two were isolated from the patients hospitalized in the internal medicine department, and two were isolated from the pediatric patients hospitalized in the pediatric infectious diseases and neonatal departments.

The only group with three microorganisms was genotype R6 (isolates 39, 8 and 31). The microorganisms with this genotype were isolated from the patients hospitalized in different departments and on different dates.

The genotypes consisting of two microorganisms were R20, R2, R7, R4, R1, R26 and R25. Among these groups, genotype R2 (isolates 15 and 2) was isolated from the patients hospitalized at the general pediatric department, while the microorganisms with genotype R20 (isolates 35 and 45), R7 (isolates 14 and 9), R4 (isolates 27 and 5), R1 (isolates 1 and 3), R26 (isolates 48 and 50) and R25 (isolates 46 and 47) were isolated from the patients of completely different departments.

Several studies have shown that PFGE genotyping of Candida spp. can be performed in the form of restriction enzyme digestion or electrophoretic karyotyping ${ }^{[17,19]}$. PFGE-EK method is used to separate chromosomal DNA in agarose gel according to their sizes ${ }^{[20]}$. 
Several previous studies obtained 5-8 bands for C. albicans by electrophoretic karyotyping ${ }^{[16,19]}$. Our study, also revealed $5-8$ bands by electrophoretic karyotyping. $\mathrm{R}$ chromosome containing rDNA genes, which can be seen as a highly variable band, exhibits different electrophoretic mobility, but generally moves equally or faster than the $1^{\text {st }}$ chromosome, and rarely slower than the $1^{\text {st }}$ chromosome. As in other studies, the results were interpreted by excluding the band formed by $\mathrm{R}$ chromosome from the evaluation in our study ${ }^{[19]}$.

Although $C$. albicans is generally considered as an endogenous pathogen, various studies have shown that it may also be an exogenous contamination from the patient to the patient or by the hands of the healthcare staff. A study by Ben Abdeljelil et al. has aimed to reveal the correlation between systemic $C$. albicans infections in neonates and healthcare staff using electrophoretic karyotyping. The study included $38 \mathrm{C}$. albicans strains isolated from patients and nurses. As a result, 38 isolates were divided into three main groups, and that there were isolates isolated from both patients and nurses in the first group. In this way, they emphasized the importance of hospital staff in nosocomial infection ${ }^{[16]}$.

Fifty $C$. albicans isolates were divided into 41 genotypes in our study by PFGE-EK method. P1 was the largest group among these genotypes with four microorganisms. Although four isolates forming Genotype P1 (isolates 1, 17, 18 and 3) were isolated from different departments, it is remarkable that the strains no. 1 and 3, 17 and 18 were isolated on close dates.

Genotypes consisting of two microorganisms were P5, P33, P26, P10, P19 and P14. Genotype P5 (isolates 6 and 7) was isolated from the patients hospitalized in the internal medicine department on close dates. Genotype P33 (isolates 39 and 40) was isolated from the patients hospitalized at the neonatal and infancy departments where there may be pediatric patients at almost close intervals. It was seen that the microorganisms forming genotype P26 (isolates 32 and 42), P10 (isolates 12 and 21), P19 (isolates 24 and 28), P14 (isolates 16 and 44) groups were isolated from the patients of completely different departments.
While PFGE-EK is a non-amplification method, AP-PCR is an amplification based method ${ }^{[21]}$. Our study aims to enhance reliability by using these two methods, each of which has different working principles. Both epidemiological typing methods used in the study did not detect a dominant epidemiological group with a large number of microorganisms. Three groups of isolates (6 and 7, 1 and 3,16 and 44) had the same genotype with both methods, while other strains were included in different genotypes.

Candida species are usually found in the normal microflora of individuals as commensal organisms. However, if the balance of the normal flora is impaired or in case of immune suppression, they often become pathogenic. This transformation from commensal to pathogen draws attention to the potential pathogenicity of $C$. albicans, which especially has extensive virulence factors. Secreted aspartic proteases form an important virulence factor for $C$. albicans, which enables to avoid host resistant mechanisms and degradation of host barriers during adhesion and invasion ${ }^{[8]}$.

Despite its high incidence rate and the significant insight into host response mechanisms that contribute to disease pathogenesis, still relatively little is understood about the fungal virulence factors that govern symptomatic immunopatho$\log y^{[22]}$.

SAP4-6 genes from secreted aspartic proteases encoded by a gene family consisting of 10 SAP genes are effective in systemic infections ${ }^{[9,23]}$. Kalkanc1 et al. have investigated the distribution of SAP in different $C$. albicans isolates. In the study, SAP4 was found in 38 (95\%) of the 40 isolates isolated from blood culture, while it was detected in $3(7.5 \%)$ of the 40 isolates isolated from vaginal cultures. According to these results, researchers commented that SAP4 was associated with systemic infections ${ }^{[23]}$.

Ardehali et al. have examined the prevalence of some virulence genes in various Candida species in their studies. The researchers detected that SAP4 gene exists in 57 (88\%) of C. albicans isolate in the study which includes strains isolated from different materials ${ }^{[24]}$. 
In our study, SAP4 gene was present in 49 $(98 \%)$ of the 50 C. albicans isolates isolated from the blood cultures. SAP4 gene negative isolate (No. 50) was among genotype R26 by AP-PCR and was similar with isolate no. 48 with a correlation of $94.7 \%$. By PFGE-EK, it did not share any similarities with any of the other isolates. Isolate numbered 48 was isolated from pediatrics and isolate numbered 50 was isolated from neurology services. PFGE is stil considered a gold standard method for the characterization of many pathogenic microorganisms ${ }^{[21,25]}$. Therefore, it is considered that AP-PCR method defines isolates numbered 48 and 50 in the same genotype mistakenly due to both PFGE-EK difference and SAP4 difference.

In conclusion, both molecular typing methods revealed that $C$. albicans isolated from blood cultures of the patients hospitalized in various departments of our hospital were generally endogenous, and may rarely be exogenous. In this context, it is necessary to attempt to eliminate the factors that may result in the formation of the infection caused by the patient's own conditions without ignoring the environmental measures in order to minimize hematogenous $C$. albicans infections in our hospital.

The detection of SAP4 gene in all of our isolates other than one draws attention to the importance of this gene in pathogenesis. Examination of the existence of SAP4 gene without invasive-noninvasive isolate comparison may be considered a missing part of our study. Comprehensive studies in which invasive and noninvasive isolates can be compared and a number of strains included may help researchers understand virulence mechanisms of $C$. albicans.

\section{ETHICS COMMITTEE APPROVAL}

Ethics committee approval is not required.

\section{CONFLICT of INTEREST}

The authors declare that they have no conflict of interest.

\section{AUTHORSHIP CONTRIBUTIONS}

Concept/Design: All of authors

Analysis/Interpretation: All of authors

Data Acquisition: KB

Writting: All of authors

Final Approval: All of authors

\section{REFERENCES}

1. Gillespie S. Medical Microbiology Illustrated. $1^{\text {st }}$ ed. Oxford: Butterworth-Heinemann Ltd, 1994.

2. Fothergill $A W$. Medically Significant Fungi. In: Mahon $C R$, Lehman DC, Manuselis G (eds). Textbook of Diagnostic Microbiology. Missouri: Saunders Elsevier, 2011:603-38.

3. Dadar M, Tiwari R, Karthik K, Chakraborty S, Shahali Y, Dhama K. Candida albicans - Biology, molecular characterization, pathogenicity, and advances in diagnosis and control - An update. Microbial Pathogenesis 2018;117:128-38.

4. Işıkgöz Taşbakan M, Eren Kutsoylu O, Pullukçu H, Sayın Kutlu S, Öztürk B, Kaya O, et al. Invaziv Kandida infeksiyonlarında anidulafungi kullanımının çok merkezli analizi. Flora 2019;24:136-42.

5. Mims C, Dockrell HM, Goering RV, Roitt I, Wakelin D, Zuckerman M. Medical Microbiology. Spain: Elsevier Limited, 2004.

6. Wibawa T. The role of virulence factors in Candida albicans pathogenicity. I med Sci 2016;48:58-68.

7. Gu W, Guo D, Zhang L, Xu D, Sun S. The synergistic effect of azoles and fluoxetine against resistant Candida albicans strains is attributed to attenuating Fungal virulence. Antimicrobial Agents and Chemotherapy 2016;60:6179-88.

8. Naglik JR, Challacombe SJ, Hube B. Candida albicans secreted aspartyl proteinases in virulence and pathogenesis. Microbiol Mol Biol Rev 2003;67:400-28.

9. Lian CH, Liu WD. Differential expression of Candida albicans secreted aspartyl proteinase in human vulvovaginal candidiasis. Mycoses 2007; 50:383-90.

10. Costa $C R$, Jesuino RS, de Aquino Lemos J, de Fatima Lisboa Fernandes O, Hasimoto e Souza LK, Passos XS, et al. Effects of antifungal agents in sap activity of Candida albicans isolates. Mycopathologia 2010;169:91-8.

11. Miyakawa Y, Mabuchi T, Fukazawa Y. New method for detection of Candida albicans in human blood by polymerase chain reaction. J Clin Microbiol 1993;31:3344-7.

12. Otlu B. Enfeksiyon etkeni olarak izole edilen Candida albicans suşları ile koloniz asuşlar arasındaki genotipik farklıIIkların pulsed field gel electrophoresis ve arbitrarily primed $P C R$ yöntemiyle araştırılması (tez). Ankara: Gazi Üniversitesi; 2004.

13. Durmaz R, Ayan M. Acinetobacter baumannii izolatlarının moleküler epidemiyolojisinde "Arbitrarily Primed" PZR ve "Pulsed-Field Gel" elektroforezi. In: Durmaz R (ed). Uygulamalı Moleküler Mikrobiyoloji. 2nd ed. Ankara: Nobel Tıp Kitabevleri, 2001:219-28.

14. Graser Y, Klare I, Halle E, Gantenberg R, Buchholz P, Jacobi $H D$, et al. Epidemiological study of an Acinetobacter baumannii outbreak by using polymerase chain reaction fingerprinting. I Clin Microbiol 1993;31:2417-20.

15. Kuzucu Ç, Durmaz R, Otlu B, Aktas E, Gulcan H, Cizmeci Z. Species distribution, antifungal susceptibility and clonal relatedness of Candida isolates from patients in neonatal and pediatric intensive care units at a medical center in Turkey. New Microbiol 2008;31:401-8. 
16. Ben Abdeljelil J, Ben Saida N, Saghrauni F, Fathallah A, Boukadida J, Sboui $H$, et al. Systemic neonatal candidosis: the karyotyping of Candida albicans strains isolated from neonates and health-workers. Mycoses 2010;53:72-7.

17. Shin JH, Og YG, Cho D, Kee SJ, Shin MG, Suh SP, et al. Molecular epidemiological analysis of bloodstream isolates of Candida albicans from a university hospital over a five-year period. I Microbiol 2005;43:546-54.

18. Xu J, Boyd CM, Livingston E, Meyer W, Madden JF, Mitchell TG. Species and genotypic diversities and similarities of pathogenic yeasts colonizing women. J Clin Microbiol 1999;37:3835-43.

19. Chen KW, Lo HJ, Lin YH, Li SY. Comparison of four molecular typing methods to assess genetic relatedness of Candida albicans clinical isolates in Taiwan. J Med Microbiol 2005;54:249-58.

20. Doi M, Homma M, Chindamporn A, Tanaka K. Estimation of chromosome number and size by pulsed-field gel electrophoresis (PFGE) in medically important Candida species. I Gen Microbiol 1992;138:2243-51.

21. Yalınay M, Baran I, Akyar I. Moleküler Mikrobiyoloji. In: Başustaoğlu A, Us D (eds). Koneman's Color Atlas and Textbook of Diagnostic Microbiology Türkçe Baskı. Ankara: Hipokrat Yayınevi, $2017: 137-72$.

22. Willems HME, Bruner WS, Barker KS, Liu J, Palmer GE, Peters BM. Overexpression of Candida albicans secreted aspartyl proteinase 2 or 5 is not sufficient for exacerbation of immunopathology in a murine model of vaginitis. Infection and Immunity 2017;85:1-12.
23. Kalkancı A, Bozdayı G, Biri A, Kuştimur S. Distributionof secreted aspartyl proteinases using a polymerase chain reaction assay with SAP specific primers in Candida albicans isolates. Folia Microbiol 2005;50:409-13.

24. Ardehali SH, Azimi T, Fallah F, Aghamohammadi N, Alimehr S, Karimi AM, et al. Molecularetection of ALS1, ALS3, HWP1 and SAP4 genes in Candida Genus isolated from hospitalized patients in intensive care unit, Tehran, Iran. Cell Mol Biol 2019;65:15-22.

25. Lopez-Canovas L, Benitez MBM, Isidron JAH, Soto EF. Pulsed Field Gel Electrophoresis: Past, present, and future. Anal Biochem 2019;573:17-29.

\section{Address for Correspondence/Yazıșma Adresi}

Dr. Öğr. Üyesi Kemal BiLGiN

Ondokuz Mayıs Üniversitesi Tıp Fakültesi, Tıbbi Mikrobiyoloji Anabilim Dalı, Samsun-Türkiye

E-mail: kemal.bilgin@omu.edu.tr 